\title{
O mojej Babci
}

Gdy zadzwonił do mnie z propozycją napisania wspomnienia o Babci Bronce mój wuj - Marcin Piotrowski (doktor i wykładowca w Katedrze Etnologii UŁ - na propozycję prof. Andrzeja Lecha), pomyślałam, że to zaszczyt, a zarazem, że Babcia byłaby bardzo szczęśliwa, że to właśnie mnie poproszono o napisanie o niej kilku słów. Dodałaby z pewnością, że to zabawne, bo przecież pomimo jej sugestii i delikatnych perswazji nie kontynuowałam obiecująco rozpoczętej w Łodzi, a kontynuowanej na Uniwersytecie w Prowansji, ścieżki naukowej - oczywiście związanej z etnologią. Nie planując doktoratu, na pewno zniszczyłam jej ciche marzenia o wnuczce idącej w jej ślady, ale co później wielokrotnie w naszych długich rozmowach podkreślała: „na dobre Ci to dziecko wyszło".

Dla większości Pani Profesor Bronisława Kopczyńska-Jaworska, dla mnie i mojej siostry, nasza ukochana Babcia Bronka, zawsze elegancka, z bladym uśmiechem, lekkim dystansem do wszystkich i wszystkiego. Niewątpliwie postać nietuzinkowa, kobieta, która wyprzedzała swoje czasy, stawiająca naukę i badania często ponad wszystko, lecz u schyłku życia wątpiąca czy jej życie miało sens, czy nie spędzała za mało czasu w domu, zastanawiająca się czemu nie poświęciła więcej czasu rodzinie.

Babcia była osobą bardzo towarzyską. Jak sama mówiła, dopiero opowiadając historie, nabierały one dla niej swojej formy i otrzymywały ostateczny kształt. Gdy kogoś lubiła, potrafiła snuć wspomnienia godzinami, przytaczając coraz to nowe anegdoty z życia naszej wielopokoleniowej łódzko-warszawskiej rodziny, do której tradycji była bardzo przywiązana. Wiele moich rozmów z Babcią dotyczyło także życia Katedry Etnologii oraz pracujących tam kolegów i koleżanek - w większości jej uczniów, kierunków badań, które były podejmowane, gdy już nie kierowała Katedrą lub jeszcze szerzej rozumianej etnografii, zmian rozwoju jej kierunków, sensu i bezsensu rozwoju tych kierunków, spłycenia badań terenowych, do których była szczególnie przywiązana, naciągania wyników badań pod modne w danych momentach teorie, bezsensu zmian w ocenie prac naukowych, podważaniu dorobku wcześniejszych pokoleń badaczy etc. etc. Babcia interesowała się wszystkim, co działo się w Katedrze, do końca swych dni, czuła się nadal jej częścią, w dużym stopniu dzięki Wujowi Marcinowi, Kasi Kaniowskiej, Ewie Karpińskiej, „Sroce”, Indze Kuźmie (którą mentalnie adoptowała), Małgosi Wilbik, Alicji Piotrowskiej. Zawsze, niby już nic nie widząc i źle słysząc, była „au courant” z nowinkami z Uniwersytetu.

Babcia miała w życiu kilka pasji, które stawały się obszarem jej badań naukowych. Pierwszą z nich, od której rozpoczęła swoją pracę naukową, były góry. 
Nie będę skupiać się na jej dokonaniach naukowych, bo o tym z pewnością ktoś napisze trafniej ode mnie.

Tatry - to było ukochane Babci miejsce na ziemi, (no może jeszcze Francję lubiła nieco bardziej, w której „gdy była piękna i młoda” była na stypendium, a potem miewała wykłady i grono uniwersyteckich przyjaciół z Eurethno), to tam na 90 urodziny chciała pojechać. Do Małego Cichego, do Morskiego Oka - popatrzeć na Tatry (Tata załatwił przepustkę w Tatrzańskim Parku Narodowym, żeby móc zawieźć Babcię autem nad Morskie Oko - o dziwo bez problemu, może dlatego że Pani Profesor jakby nie było widnieje w „Encyklopedii Tatrzańskiej”, pobyć tam raz jeszcze. Świętowaliśmy jej urodziny szampanem z widokiem na świeżo zieloną majową Rusinową Polanę u zaprzyjaźnionych od pokoleń gazdów - u Parów.

Drugą miłością jej życia były historie rodzinne, które opowiadała nam od dziecka, które na szczęście spisała, z lekkim zacięciem naukowym i precyzją, i które dzięki temu, pozostaną nie tyko we wspomnieniach, ale także na stronach maszynopisu, ubarwione zbieranymi fotografiami. Moja siostra - Marta Gerlicz opracowuje je aktualnie i zgodnie z Babci marzeniem, które niestety za jej życia się nie zrealizowało, planujemy je wydać w formie książkowej (Babcia zawsze mówiła, że „to może lepiej wydać jak już umrę, bo wtedy nikt nie się na mnie nie obrazi”). To dzięki Babci wiem o pasjach motoryzacyjnych wujka Tomasza Domaniewskiego, kto to była Janeczka Polakówna, kim jest Krzysztof Libin, po kim mam imię - Jagusia, że pastor Bursche miał dwie córki Jagodę i Malinę, wiem, że dziadek Ignaś świetnie gotował, że mała Tereska chodziła na spacery z pieskiem w czasie wojny w Warszawie z Grenadierów na Saską Kępę z tzw. „bibułą”, że Ciocia Zosia była bardzo zdolna i najlepiej mówiła po francusku, że kiedyś klient naszej rodzinnej piekarni oddał zapieczoną w chlebie obrączkę dziadka, że Wujek Zbyszek Kopczyński stracił w wypadku syna, który był bardzo przystojny i wiele, wiele innych szczegółów z życia naszej dużej rodziny. To dzięki Babci wszystkie postaci dla niej teraźniejsze były bliskie także dla nas. To są pewne wartości nie do zastąpienia, przywiązanie do pochodzenia, do bliskich, do kultury, do szacunku dla różnorodności, akceptacja religijności lub jej braku wśród najbliższych. Babcia była dal nas chodzącym wzorem i przykładem, choć nigdy nie uważała się za ideał.

Trzecią miłością Babci były książki, tę miłość oddała nam wszystkim nieodwracalnie. To dla niej chciało się czytać wciąż nowe powieści, by mieć temat do długich rozmów, często w naszej ciasnej góralskiej jadalni w ukochanym domu w Łodzi. Uwielbiała biografie, autobiografie i coś na kształt, co zawsze ją drażniło, gdy jej to wytykałam, literatury plotkarskiej: dzienniki, wspomnienia. Niezależnie od ich poziomu literackiego, dotykały one rzeczywistości, a to ona ją najbardziej interesowała. W późniejszych latach, gdy Babcia już słabo widziała, zamawialiśmy dla niej audiobooki, miała całe listy tych, które już ma, czytałam jej opisy ze stron internetowych i szukałyśmy razem ciekawych książek. Niestety, a może „stety” zainteresowania Babci wykraczały często poza oferowane przez komercyjne serwisy pozycje, więc nagrywałam jej własne: pisma naukowe, 
„Moją lwią rodzinę”, czy życie międzywojennej Warszawy. Babcia bardzo to doceniała i zawsze chwaliła, „że tak ładnie czytasz i wymawiasz obce nazwiska”, i że mogłabym być lektorem, jak już znudzi mi się zajmowanie „tymi Twoimi szarpidrutami” (jestem managerem rockowego zespołu Perfect). Pomagały jej też „dziewczyny” - czyli studentki etnologii - czytały, prowadziły korespondencję itp. (Monika, Patrycja i Anie).

Babcia była dla mnie drogowskazem, potrafiła nieświadomie rzeczy skomplikowane zamieniać w proste, jak zdanie, które do dziś pomaga mi w trudnych sytuacjach, komentujące relacje z ludźmi: „Ależ Jagusiu, przecież ten Pan nie mógłby mnie obrazić”...

O poczuciu własnej wartości mogłaby wiele opowiedzieć, gdyby chciała, ale nigdy tego nie robiła. Nie zawsze umiała wyrazić co czuje, jak np. miłość do mojego Taty, dla którego oddałaby wszystko. To w trosce o niego, żeby nie został sam, tak bardzo dbała o zdrowie, że przez ponad 92 lata była z nami, patrząc jak wszyscy wokół niej odchodzą, rodzice, mąż, synowa, siostry, kuzyni, kuzynki, przyjaciele. Była ostatnim ogniwem łączącym nas z przeszłością. Teraz musimy sobie radzić sami bez jej parasola ochronnego otwartego nad nami wszystkimi. Od jej śmierci minęło już 9 miesięcy, a skłamałabym, gdybym napisała, że Babci z nami już nie ma. Jest, jesteśmy przesiąknięci jej spojrzeniem na świat, jej reakcjami, jej powiedzonkami, jej pytaniami. Siedząc na lotnisku w Wenecji i kończąc to krótkie wspomnienie o niej, wiem, że spytałaby mnie po powrocie do Polski, czy na pewno poszłam na koncert Vivaldiego i czy odwiedziłam szklarzy na Murano (bo miała taki piękny przycisk do papieru, który bardzo lubiła - właśnie stamtąd).

Babcia nauczyła nas czegoś najważniejszego w życiu, ciekawości świata, wartości ponad podziałami. Pochodząc z rodziny wieloreligijnej, nauczyła nas, że zawsze warto wiedzieć więcej o drugim człowieku, na każdy temat, że rodzina jest ważna ponad wszystko inne... no, chyba że trzeba było wyjechać na stypendium do Paryża, pojechać robić badania terenowe czy po prostu spotkać się z przyjaciółmi w Izraelu. Nauczyła nas, że w Boże Narodzenie je się karpia na stojąco (karp pieczony w całości na chlebie) i że uszek do barszczu nigdy nie będzie za dużo, czy się ich zrobi 300 czy 400, czy 500. Zdania, że „można by” np. posprzątać lub „trzeba by” iść do sklepu brzmią mi nadal w uszach - tej ulubionej formy wydawania poleceń też nas nauczyła. Łapię się coraz częściej na tym, że sama jej używam nieświadomie.

Na pogrzebie Babuni, na jej ulubionym łódzkim Starym Cmentarzu na Ogrodowej w Łodzi, spotkało się bardzo dużo ludzi. Babcia powiedziałaby na pewno, że to „zabawne”, że tak liczne grono przyszło ją pożegnać i na pewno byłaby szczęśliwa, że tak na początku roku wszyscy są razem, bo ponad wszystko lubiła spotkania towarzyskie.

Będzie mi Ciebie Babciu bardzo brakowało.

Jagusia

(Agnieszka Jaworska) 